\title{
Right to Education: A Viewpoint
}

\author{
Aruna Shanmuganathan \\ Consultant Pulmonologist, Chettinad Hospital, Chennai. \\ Corresponding Author: Aruna Shanmuganathan \\ E-mail: draruna.shanmuganathan@gmail.com
}

A viewpoint on RTE is essentially a statement of political ideology. If you believe, as I do, that "free markets" create the greatest wealth for the society with reducing inequalities, then an act such as the RTE is retrograde and ought to be abolished. A more appropriate question to address would be "Given the current socio-economic fabric of our society today, what can the Government do to deliver better education to its citizens?"[1].

\section{Background}

The Right of children to free and compulsory education Act or the RTE, is an act of Parliament of India enacted on Aug 04 $4^{\text {th }}, 2009$. This describes the importance of free and compulsory education for children between 6 and 14 in India under Article 21 of the Indian Constitution. India thus joined the list of 135 countries to make elementary education a fundamental right of every child between 6 and 14 years of age under the Right To Education (RTE) act which came into force from Apr 01, 2010 [2].

Some of the other salient provisions of the RTE Act include the No Detention Policy ie every student will automatically be promoted upto class eight(though this has recently been modified after the NITI Aayog recommendations), 25\% reservation of seats in Private schools for underprivileged children, admission of children based on age to the respective class, prohibiting unrecognised schools from admission and ban on collection of capitation fees and conducting interviews.

\section{What is Real Education}

The UNESCO defines Education based on the 4 pillars of Learning namely, learning to do, learning to be, learning to know and learning to live together. Basically, it is important to understand that the concept of Education should be holistic. It should not only involve feeding students with information and knowledge. Instead, Education should be able to empower students to bring out their potential strengths so that they are able to perform and deliver not only to their betterment but also contribute and give back to society in a meaningful manner [3].

\section{Do we need an RTE Act at all}

Whether we need RTE or not depends on the "Economic Philosophy" we subscribe to. India has been moving from a Socialistic system towards a "Command Capitalism". For a Socialist system, RTE would be a mandatory act. For a Markets based society, RTE would be viewed as detrimental to the cause of education.

Socialism is always the best system on paper - equality \& egalitarianism, sounds noble \& humane. But remember that the "Road to Hell is paved with the best of intentions". I personally subscribe to Market Capitalism as the system that will deliver India out of poverty, illiteracy and malnutrition [4]. 


\section{Challenges in the RTE Act}

The Challenges could be viewed at two levels. One is at the conceptual level and the other at the implementation level.

At a conceptual level, RTE will be viewed through the prism of politico-economic ideology that all of us, either consciously or sub-consciously subscribe to. Broadly speaking, the spectrum of these ideologies range from Communism to Libertarianism. While communists would view RTE as an integral aspect of societal development, Libertarians would view the same as another one of those regulatory systems that creates inefficiencies, directs power away from the markets / citizens and results in misallocation of scarce resources. However, since this aspect depends on the individual ideology and since the RTE Act is already existent there is no use in further debating this. It would be hence better to consider the challenges at the implementation level which if addressed, could lead to effective achievement of the goals of the RTE Act [5].

The RTE Act is riddled with several issues at the Implementation level. I shall try to highlight a few major ones with suggestions to modify them for better end results.

\section{The No Detention Policy}

This provision allows for automatic promotion of a student till Class 8 (though this has undergone modifications recently at State levels). It was mainly implemented with the purpose of reducing the school drop-out rates. This on the contrary, has translated into worse outcomes in terms of learning for the students. According to the data from The Central Advisory Board on Education (CABE,2014), National Achievement Survey (2012) and the Economic Survey (2016-17), it was observed that the learning levels in elementary education declined after the implementation of the RTE Act. At the national level, $73 \%$ of children in class 3 were unable to do basic arithmetic. The Annual Status of Education Report (ASER)in 2014 showed that more than 50\% of 5th graders could not even read standard second class level textbooks. Hence this free pass system drives out the incentive to learn in students and to teach in teachers. The very purpose of education is thus lost [6].

\section{Quality of Education in Public schools and the Cost Factor}

Despite an enormous capital allocation, the quality of education in public schools has been going down over the last few decades. In Government schools, the per pupil cost is upto 20 times higher than some low fee private schools. Almost $50 \%$ of children in India (31\% from rural and $80 \%$ from urban) go to private schools. Even the majority of our domestic maids and helpers send their children to private schools. This reflects on the pathetic quality of Education provided in many of the public schools, although the pay of an average public school teacher is at least 2-3 times higher compared to that of a private school teacher. Also, the infrastructure of majority of the public schools is way under satisfactory. All this despite huge government expenditure and Committees to oversee their functioning [7].

\section{Forced Economic Diversity in Classrooms}

Since the RTE Act provides for $25 \%$ reservation for the underprivileged students, this often translates into traumatic experiences for such students as there is an inevitable discrimination between the haves and have nots. Though there are views that this diversity leads to better adjustments between children, in majority of the cases it leads to many psychological and behavioral problems. Another disadvantage of this provision is the inefficiency of the government machinery causing inordinate delays in reimbursement to these private schools. As a result, many unaided schools are reluctant to follow this provision as it leads to unnecessary capital loss [8].

\section{Lack of Accountability of teachers}

There is no provision in the Act to supervise the performance of the teachers in public schools. Also, there are far few numbers of teachers who are trained in these schools. 


\section{Possible Solutions}

- "Education Vouchers" delivered directly to parents would enable competition among schools to improve their education and teaching systems while removing the financial burden from the parents and also lead to better capital utilisation. This has successfully been implemented in countries like Sweden, Chile and Italy.

- Do Away with the Free Pass System

- Place the onus on the stakeholders ie student, teachers and parents for learning outcomes and incentivise the performance for all stakeholders.

- More Accountability and Transparency in the System is necessary

As it stands today, the RTE act has a number of challenges that need to be addressed at multiple levels in order to achieve the very purpose of it being conceptualised.

\section{REFERENCES}

1. Mehrotra S. The cost and financing of the right to education in India: Can we fill the financing gap?. Int J Education Dev 2012;32(1):65-71.

2. Sripati $V$, Thiruvengadam AK. India: Constitutional amendment making the right to education a Fundamental Right. Int J Constitutional Law 2004;2(1):148-58.

3. Agrawal T. Educational attainment in educationally backward states of India: some implications for the right to education act. Int J Educ Econ Dev 2013;4(1):89-99.

4. Kaushal M. Implementation of Right to Education in India: Issues and Concerns. J Managem Pub Policy 2012;4(1):1-5.

5. Jha P, Parvati P. Assessing progress on universal elementary education in India. Economic and Political Weekly 2014;49(16):44-51.

6. Kalyanpur M. Equality, quality and quantity: challenges in inclusive education policy and service provision in India. Int J Inclusive Educ 2008;12(3):243-62.

7. Stromquist NP, Monkman K, editors. Globalization and education: Integration and contestation across cultures. R\&L Education; 2014.

8. Jha P. Guaranteeing elementary education: a note on policy and provisioning in contemporary India. J South Asian Dev 2007;2(1):75-105.

\section{Acknowledgements - Nil \\ Source of Funding - Nil \\ Conflict of Interest - Nil}

